\title{
A Comparison on Termite Assemblages in Coffee \& Teak Plantations and Semi-Evergreen Forest - A case study in North Wayanad, Kerala, India
}

\author{
K.V. Bhavana, Amina Poovoli ${ }^{1 *}$, K. Rajmohana ${ }^{1}$ and M. Shweta ${ }^{1}$ \\ Department of Zoology \\ Kannur University \\ Mananthavady campus, Kerala, \\ India
}

\begin{abstract}
In tropical ecosystems, termites as organic decomposers, play a key role in modifying the biotic and abiotic environment. The present study aimed to investigate how the termite diversity and assemblages differed among habitats. Three sites in North Wayanad, Kerala, India,- a teak plantation, a coffee plantation and a semi-evergreen forest, that were structurally different and with varying land use histories- were chosen for this study. Belt transect method was used to sample the termites. The study recorded a total of 10 species in 7 genera belonging to 4 subfamilies under one family. Termite assemblages and feeding group structure differed significantly among habitats. Two functional groups were recorded-Type II (fungus growing wood feeders/litter feeders, micro epiphytes) and Type III (organic rich soil feeders/ humus feeders). Fungus growing wood/litter feeders were dominant in plantations whereas organic rich soil/humus feeders were dominant in forest region. Plantations seem to host more, species like Odontotermes obesus Rambur, Odontotermes anamallensis Holmgren and Holmgren and Odontotermes yadevi Thakur, the species being good colonizers, favoured by disturbance and also those with the potential of becoming pests. The species diversity, richness, evenness as well as beta diversity were computed for the three habitats. Assemblages of species from the teak and coffee plantations yielded the highest similarity index (42\%). Overall, the termite assemblages and structural attributes of coffee \& teak plantations and semi-evergreen forest advocated termites as good biological indicators of habitat quality.
\end{abstract}

Keywords: Biological indicator, functional group, coffee and teak plantation, termites, semievergreen forest, diversity.

\section{INTRODUCTION}

The termites are the most dominant arthropod decomposers in the tropical forests (Wood and Sands, 1978; Matsumoto and Abe, 1979; Collins, 1983) and they show high diversity and abundance (Bignell and Eggleton, 2000). Within tropical ecosystems, termites play a key role in modifying the biotic and abiotic environment. They become economic pests when their appetite for wood and wood products extends to human homes, building materials, forests, and other commercial products (Meyr, 2009). Approximately 2,700 described

1 Zoological Survey of India, Western Ghat Regional Centre, Calicut, Kerala-673006, India

*. Corresponding author: aminapoovoli@gmail.com 
species of termites are known globally, but only $10 \%$ of known species has been reported as pests (Wood, 1996).

The diversity and distribution of termites are greatly influenced by factors such as vegetation type (Jones, 2000), habitat disturbance (Jones et al., 2003, DeBlauwe et al., 2008) and habitat fragmentation (DeSouza \& Brown, 1994, Davies et al., 2003). Hence termites have been used as indicator species to study the effect of land use conversion on biodiversity in several areas (Eggleton et al., 1996, Dibog et al., 1999).

The present study by comparing the termite assemblages of a semi-evergreen forest with those of two plantations namely coffee and teak, aimed to investigate how the termite diversity and assemblages differed among habitats. The results advocate the potential of termites as efficient ecological indicators.

\section{METHODOLOGY}

\section{Study area}

The present study was carried out at three selected representative sites in Wayanad district (Table 1), situated in the southernmost Indian state of Kerala, a place well known for its high degree of endemism and richness of flora and fauna (Fig.1). Set high on the Western Ghats with north latitude $11^{\circ} 26^{\prime} 28^{\prime \prime}$ and $11^{\circ} 58^{\prime} 22^{\prime \prime}$, east longitude $75^{\circ} 46^{\prime} 38^{\prime \prime}$ and $76^{\circ} 26^{\prime} 11^{\prime \prime}$, the altitude ranges from 700 to $2100 \mathrm{~m}$. The average rainfall is $2322 \mathrm{~mm}$ per year. The description of the sample site is given in Table 1.

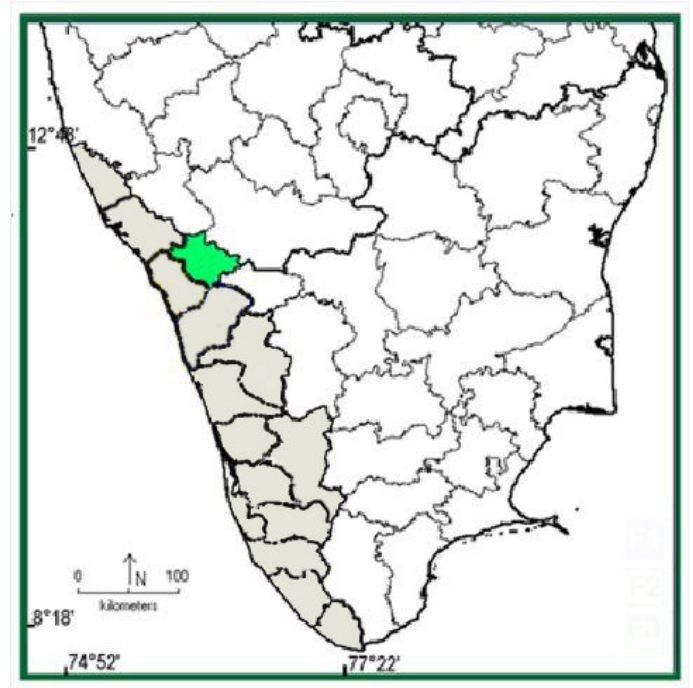

Fig.1. The study area, Wayanad (Kerala) 


\section{Study sites in Wayanad}

\section{Site 1: Coffee plantation at Kartikulam}

The coffee plantation selected for this investigation was situated at Kartikulam of Mananthavady taluk (Fig.2-A), about $9.5 \mathrm{~km}$ away from Mananthavady town $\left(11^{0} 84773\right.$ " N and $76^{\circ} 09661$ " E, altitude 776 to $793 \mathrm{msl}$ ). In the plantation, other trees like Dalbergia sp., Erythrina sp., Atrocarpus sp., Grevillea sp. and many other varieties of plants were fond as shade plants. The surface soil was highly enriched with leaf litter and decaying wood particles.

\section{Site 2: Teak plantation at Tholpetty}

Wayanad hosts extensive areas of reserve forests, of which the major components are the

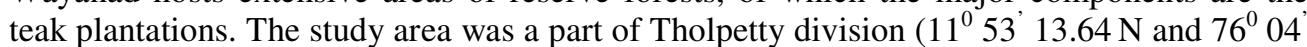
35.63 " E, $747.37 \mathrm{msl}$ ) of Wayanad Wildlife Sanctuary, an integral part of the Nilgiri Biosphere Reserve (Fig. 2-B).

\section{Site 3: Semi- evergreen forest at Thirunelli}

The area under investigation was situated in the semi-evergreen forest region of Thirunelli $\left(11^{0} 54^{\prime} 51.45^{\prime}\right.$ N $, 75^{0} 59^{\prime} 39.55^{\prime \prime} \mathrm{E}, 900 \mathrm{msl}$ ) (Fig.2-C). This forest type was an intermediate between the tropical evergreen and deciduous forms and included both evergreen and deciduous trees. The area sampled was situated on either sides of Papanasini river. Major flora included Atrocarpus integrifolia, Dalbergia latifolia, Lagerstroemia latifolia, Pterocarpus marsupium, Macaranga peltata and shrubs like Strobilanthes kuthianus and Mesua ferrea etc. The soil surface had a dense covering of leaf litter and decaying wood particles.

\section{Table 1. Description of sample sites to study termite assemblage}

\begin{tabular}{llllll}
\hline Site & Vegetation type & Location & Latitude & Longitude & Figure \\
\hline 1 & Coffee Plantation & Kartikulam & $11^{0} 847733^{\prime \prime} \mathrm{N}$ & $76^{0} 09661^{\prime \prime} \mathrm{E}$ & $\mathrm{A}$ \\
2 & $\begin{array}{l}\text { Teak Plantation } \\
3\end{array}$ & $\begin{array}{l}\text { Semolpetti } \\
\text { forest }\end{array}$ & $11^{0} 53^{\prime} 13.64 \mathrm{~N}$ & $76^{0} 04^{\prime} 35.633^{\mathrm{E}}$ & $\mathrm{B}$ \\
& Thirunelli & $11^{0} 544^{\prime} 51.45^{\prime \prime} \mathrm{N}$ & $75^{0} 59^{\prime} 39.55^{\prime \prime} \mathrm{E}$ & $\mathrm{C}$ \\
\hline
\end{tabular}

\section{Collection of samples}

Termite samples from the selected areas were collected for a period of 3 months from September to November 2013 at weekly intervals. Standardized transect method of Jones and Eggleton (2000) was used for sampling. A belt transect, measuring $100 \times 2 \mathrm{~m}$ was laid in each site, which was in turn divided into 20 contiguous sections of $5 \times 2 \mathrm{~m}$. Each site had two representative plots separated by a distance of $50 \mathrm{~m}$. Termites were collected simultaneously at weakly intervals. A total of 5 hours were taken to search for termites in the total transect area. Microhabitats like surface soil, leaf litter and humus on the surface; at the base of trees, between roots, inside and beneath the dead woods, in mounds and on vegetations and trees up to a height of a man (about $2 \mathrm{~m}$ ) and the soil up to a depth of $5 \mathrm{~cm}$ were searched. Preferentially soldier and worker castes were collected and were stored in $70 \%$ alcohol. 
Identification of termites at species level was performed following Chhotani (1997). Major generic diagnostic characters of soldiers and workers are given in Table 2. All specimens are deposited in the National Zoological Collections of the Zoological Survey of India (ZSI), at Calicut (Kozhikode), Kerala, India.

Table 2. Major diagnostic characters of soldiers and workers of different termite genera

\begin{tabular}{|c|c|c|}
\hline \multirow[t]{2}{*}{ Termite genera } & \multicolumn{2}{|c|}{ Major diagnostic characters } \\
\hline & Soldier & Worker \\
\hline Odontotermes Holmgren & $\begin{array}{l}\text { Monomorphic, medium to fairly large } \\
\text { species, head sparsely hairy. Left } \\
\text { mandible with a small to prominent } \\
\text { tooth. }\end{array}$ & $\begin{array}{l}\text { Monomorphic or dimorphic. } \\
\text { Head capsule subsquarish. } \\
\text { Fontanelle plate round and } \\
\text { oval. Antennae with 17-19 } \\
\text { segments. }\end{array}$ \\
\hline $\begin{array}{l}\text { Microtermes } \\
\text { Wasmann }\end{array}$ & $\begin{array}{l}\text { Monomorphic, small and delicate } \\
\text { species, head oval, densely hairy. } \\
\text { Mandible thin, delicate and weakly } \\
\text { incurved distally. }\end{array}$ & $\begin{array}{l}\text { Dimorphic. Head capsule } \\
\text { subsquarish. } \\
\text { indistinct. Antennae with 13- } \\
16 \text { segments. }\end{array}$ \\
\hline Speculitermes Wasmann & $\begin{array}{l}\text { Head subrectangular, large, prominent } \\
\text { and highly chitinised. Mandible } \\
\text { strongly built and long; comparatively } \\
\text { thinner basally and fairly well curved } \\
\text { apically; each with a prominent } \\
\text { triangular tooth. Antennae 14- } \\
\text { segmented. }\end{array}$ & $\begin{array}{l}\text { Head capsule subcircular. } \\
\text { Mid-dorsal spot small to fairly } \\
\text { large; either flush with head } \\
\text { surface or swollen and raised. } \\
\text { Antennae } 14 \text { segmented. }\end{array}$ \\
\hline Nasutitermes Dudley & $\begin{array}{l}\text { Monomorphic. Head not constricted } \\
\text { behind antennae. Head pyriform or } \\
\text { round. Rostrum long, narrow, } \\
\text { cylindrical to conical. Mandible with } \\
\text { short or without spine-like process }\end{array}$ & $\begin{array}{l}\text { Generally monomorphic } \\
\text { sometime dimorphic. Head } \\
\text { capsule subsquarish to broad } \\
\text { and oval. Antennae with } 13-15 \\
\text { segments. }\end{array}$ \\
\hline $\begin{array}{l}\text { Grallatotermes } \\
\text { Holmgren }\end{array}$ & $\begin{array}{l}\text { Monomorphic. Head not constricted } \\
\text { behind antennae. Head greatly } \\
\text { produced behind and strongly } \\
\text { depressed at base of rostrum in } \\
\text { profile. Rostrum short, thick and } \\
\text { conical. Mandible with well } \\
\text { developed, long spine-like process. }\end{array}$ & $\begin{array}{l}\text { Head brown to black; broad } \\
\text { and oval. Antennae with 12-15 } \\
\text { segments. }\end{array}$ \\
\hline & $\begin{array}{l}\text { Mandibles strongly asymmetrical, left } \\
\text { mandible strongly twisted at middle. }\end{array}$ & $\begin{array}{l}\text { Head capsule subcircular } \\
\text { Fontanelle plate translucent }\end{array}$ \\
\hline Dicuspiditermes Krishna & $\begin{array}{l}\text { Antero-lateral corners of head } \\
\text { produced into tubercle-like projection. } \\
\text { Antennae } 14 \text { segmented. }\end{array}$ & $\begin{array}{l}\text { and oval. Antennae } 14 \\
\text { segmented. }\end{array}$ \\
\hline $\begin{array}{l}\text { Pseudocapritermes } \\
\text { Kemner }\end{array}$ & $\begin{array}{l}\text { Mandibles strongly asymmetrical, left } \\
\text { mandible strongly twisted at middle, } \\
\text { distal tip of left mandible bent like a } \\
\text { beak. Antero-lateral corners of head } \\
\text { not produced into tubercle-like } \\
\text { projection. Antennae } 14 \text { segmented }\end{array}$ & $\begin{array}{l}\text { Head capsule subcircular. } \\
\text { Fontanelle plate translucent, } \\
\text { large and circular. Antennae } \\
\text { 13-14 segmented. }\end{array}$ \\
\hline
\end{tabular}



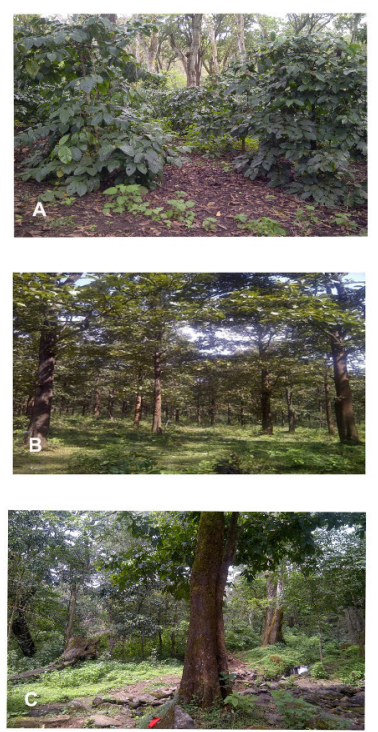

Fig. 2 (A-C): Different study sites in Wayanad

A. Coffee Plantation at Kartikulam
B. Teak Plantation at Thorpetti

\section{RESULTS AND DISCUSSION}

\section{Termite species identified}

A total of 92 termite colonies were collected from the sites during the study. Termites collected from the two plantations were identified upto species level. They belonged to the family Termitidae under 4 subfamilies (Macrotermitinae, Nasutitermitinae, Termitinae and Apicotermitinae), in 7 genera (Odontotermes Holmgren, Nasutitermes Dudley, Dicuspiditermes Krishna, Grallatotermes Holmgren, Microtermes Wasmann, Pseudocapritermes Kemner and Speculitermes (Wasmann). A total of 10 species identified were Odontotermes obesus Rambur, O. anamallensis Holmgren and Holmgren, O. yadevi Thakur, Nasutitermes matangensis matangensis Haviland, N. indicola, Grallatotermes niger Chatterjee and Thapa Dicuspiditermes incola Wasmann, Microtermes unicolor Snyder (Amina et al. in press), P.nr fletcheri and S. chadaensis Chatterjee and Thapa .

\section{Termite diversity}

The Termite diversity at generic in the three study areas are presented in Table 4 . In coffee plantation 3 genera belonging to 3 subfamilies were recorded and from teak plantation 2 subfamilies represented by 3 genera were obtained, whereas from the forest region site, 5 genera belonging to 4 subfamilies were recorded. In all the three study sites, genus Odontotermes was the most common and dominating genus. Two genera Nasutitermes and Dicuspiditermes were common to both the coffee plantation and the semi evergreen forest, whereas Grallatotermes and Microtermes were present only in the teak plantation. Speculitermes and Pseudocapritermes were confined to forest area. 
Table 3. Diversity indices for the three habitats

\begin{tabular}{llll}
\hline Diversity index & $\begin{array}{l}\text { Semi-evergreen } \\
\text { forest }\end{array}$ & Coffee plantation & Teak plantation \\
\hline Simpson's Index & 0.80 & 0.63 & 0.52 \\
Shannon-Wiener index $\left(H^{\prime}\right)$ & 1.66 & 1.10 & 0.97 \\
Margalef index $(a ́)$ & 1.73 & 1.14 & 1.21 \\
Pielou's index $(E 1)$ & 0.24 & 0.22 & 0.19 \\
\hline
\end{tabular}

From Table 3, the Simpson's index of diversity values was found to be highest for the semievergreen forest (0.80), followed by the coffee (0.63) and teak plantations (0.52). A similar trend was observed for the $H^{\prime}$ values, indicating that species diversity for the forest ecosystem, rich in humus was higher compared to the plantations. The á values for the forest ecosystem was clearly higher (1.73) than that of the plantations, with a more or less similar á value for the teak (1.21) and coffee plantation (1.14). The El values for the three habitats revealed that species distribution was most even in the forest ecosystem $(0.24)$ followd by the coffee $(0.22)$ and teak $(0.19)$ plantations.

The overall Jaccard index $(J I)$ between the three habitats was found to be $21 \%$. When the $J I$ values for the habitats taken in pairs was computed, it was found that the highest similarity in species was for the plantation crops- coffee and teak (42\%). The similarity in the habitat and community structure of the plantations, clearly reflected the correlation in the species assemblages.

The $J I$ for the forest $V s$ coffee plantation as well as forest $V s$ teak plantation generated same value of $33 \%$.

\section{Species abundance}

Of the identified termite species in coffee and teak plantation and semi-evergreen forest, their abundance showed a huge variations as shown in Table 4. A total of 5 species were obtained from coffee and teak plantations and 7 species from the forest area. Genus Odontotermes had the largest representation in all the study sites. Three Odontotermes species $O$. yadevi, $O$. anamallensis and $O$. obesus were recorded from coffee \& teak plantation plantations and the semi ever green forest. $O$. obesus was the dominating species in teak, whereas in coffee and forest sites $O$. anamallensis was found. N. matangensis matangensis was recorded only from coffee plantation whereas, G. niger and M. 'unicolor were recorded only from the teak plantation. $D$. incola was recorded in forest and coffee, while, $S$. chadaensis and $P$. near fletcheri were represented only the forest (Table 4).

Among the 33 termite colonies collected from the coffee plantation, 15 belonged to $O$. anamallensis followed by $O$. obesus (14 colonies), N. matangensis matangensis ( 2 colonies), $D$. incola and $O$. yadevi ( 1 colony each). From the teak plantation, the total collection of 27 termite colonies included 18 colonies of $O$. obesus, 6 colonies of $O$. yadevi and 1 colony of $O$. anamallensis, G. niger and M. unicolor each. The 32 collections of the semi evergreen forest region, $O$. anamallensis (11 colonies), followed by $N$. indicola (7 colonies), $P$. near fletcheri (6 colonies), O. obesus (4 colonies), D. incola (2 colonies) S.chadaensis and $O$. yadevi (1 colony) were collected. 


\section{Termite feeding groups}

The termite species collected from the study sites belonged to two feeding groups according to the classification of Donovan et al. (2001) they included Type II (wood /litter feeders, micro epiphytes feeders) and type III (organic rich soil/humus feeders) feeders. Type I (lower termites; wood feeders) and Type IV (true soil feeders) were absent in all the study sites (Fig. 3-5 and Table 4).

Out of the total of 10 species recorded, 4 species were fungus growing wood/litter feeders (O. obesus, O. anamallensis, O. yadevi and M. unicolor), 3 were organic rich soil/humus feeders (D. incola, S. chadaensis and P. near fletcheri) (Bignell et al., 2010), N. matangensis matangensis was a wood feeder (Jones and Brendell, 1994) and $N$. indicola belonged to non fungus growing wood/litter feeders, based on the mandible structure of the worker castes. In coffee and teak plantations, wood/litter feeders were dominant and while in the semi evergreen forest, organic rich soil/humus feeders were dominant. The organic rich soil/humus feeder $D$. incola was found in the coffee and in the forest. The lichen feeders or micro epiphytic feeder Grallatotermes were confined to the teak plantations. The organic rich soil/humus feeders, $S$. chadaensis and $P$. near fletcheri were recorded only from the semi evergreen forest.

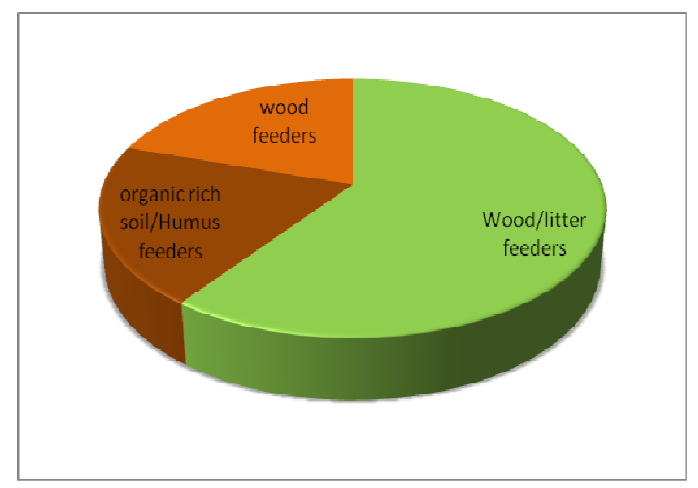

\section{Fig.3. Feeding groups - Coffee plantation}

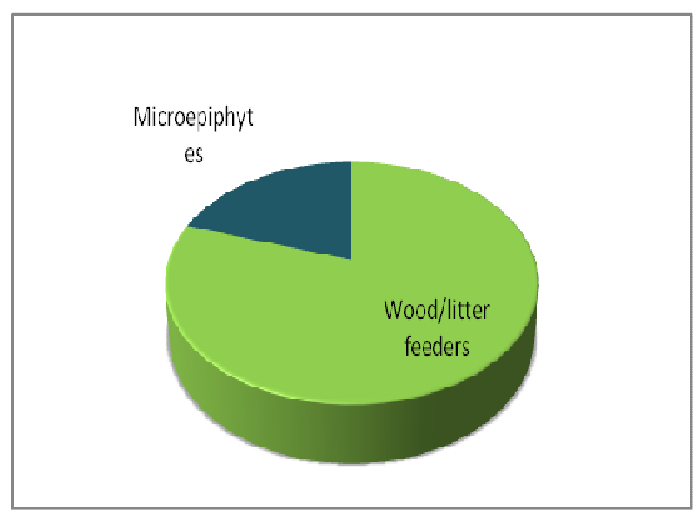

Fig.4. Feeding groups - Teak plantation 


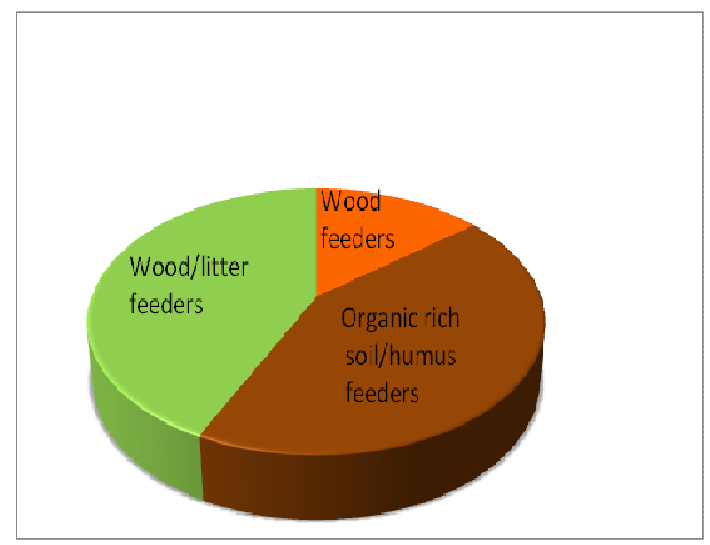

Fig.5. Feeding groups - Semievergreen forest

Table 4. Termite fauna of coffee $\&$ teak plantations and semi-evergreen forest studied in Kerala, India

\begin{tabular}{|c|c|c|c|c|c|c|c|c|}
\hline \multirow{4}{*}{ Subfamily } & \multirow{4}{*}{ Termite species } & \multicolumn{3}{|c|}{ Habitat } & \multirow{2}{*}{\multicolumn{4}{|c|}{ Food }} \\
\hline & & \multicolumn{3}{|c|}{ No. of colonies } & & & & \\
\hline & & SEF & $\mathbf{C P}$ & TP & $\mathbf{W}$ & $\mathbf{W} / \mathbf{L}$ & ME & $\mathbf{H}$ \\
\hline & & \multirow[t]{2}{*}{11} & \multirow[t]{2}{*}{15} & \multirow[t]{2}{*}{1} & & \multirow[t]{2}{*}{$*$} & & \\
\hline \multirow[t]{4}{*}{ Macrotermitinae } & $\begin{array}{l}\text { 1.Odontotermes } \\
\text { anamallensis Holmgren }\end{array}$ & & & & & & & \\
\hline & $\begin{array}{l}2 \text { Odontotermes obesus } \\
\text { Rambur }\end{array}$ & 4 & 14 & 18 & & $*$ & & \\
\hline & $\begin{array}{l}3 \text { Odontotermes yadevi } \\
\text { Thakur }\end{array}$ & 1 & 1 & 6 & & $*$ & & \\
\hline & $\begin{array}{l}4 \text { Microtermes unicolor } \\
\text { Snyder }\end{array}$ & & & 1 & & $*$ & & \\
\hline Apicotermitinae & $\begin{array}{l}5 \text { Speculitermes } \\
\text { chadaensis Chatterjee } \\
\text { and Thapa }\end{array}$ & 1 & & & & & & $*$ \\
\hline \multirow[t]{3}{*}{ Nasutitermitinae } & $\begin{array}{l}\text { 6.Nasutitermes } \\
\text { matangensis } \\
\text { matangensis Haviland }\end{array}$ & & 2 & & $*$ & & & \\
\hline & 7 Nasutitermes indicola & 7 & & & $*$ & & & \\
\hline & $\begin{array}{l}8 \text { Grallatotermes niger } \\
\text { Chatterjee and Thapa }\end{array}$ & & & 1 & & & $*$ & \\
\hline \multirow[t]{2}{*}{ Termitinae } & $\begin{array}{l}9 \text { Dicuspiditermes } \\
\text { incola } \text { Wasmann }\end{array}$ & 2 & 1 & & & & & $*$ \\
\hline & $\begin{array}{l}10 \text { Pseudocapritermes } n r \\
\text { fletcheri }\end{array}$ & 6 & & & & & & $*$ \\
\hline
\end{tabular}

Foot note:

SEF: Semi-evergreen forest

CP: Coffee Plantation

TP: Teak plantation

Feeding Group II: W= Wood, W/L=Wood/Litter, ME= Microepiphytes

Feeding Group III: $\mathrm{H}=$ Humus 
Several studies have shown that species diversity and richness of termites decrease with increase in altitude and temperature (Gathorne- Hardy et al., 2001; Donovan et al., 2002). In this study, a total of 10 species belonging to 7 genera 4 subfamilies and one family were recorded. Hence, the low diversity and richness noticed may be attributed to the high elevation of the study sites (Gathorne- Hardy et al., 2001).

Termite assemblage and feeding group structure differed significantly among habitats. As per the results of the study, subfamily Macrotermitinae was the most dominant group in plantations. The results of this study corroborated with results of Attignon et al. (2005), which recorded Macrotermitinae as the most dominating groups in termite assemblages in West - African semi deciduous forest and teak plantations.

Varma and Swaran (2007) in Eucalyptus plantations and Gowda et al. (1995) in coffee plantation reported that Odontotermes, feeding on the bark and living tissues, as the most dominant termite group in plantations. The present study confirmed the dominance of Odontotermes in plantations. Species of Odontotermes ie. O.obesus, O.anamallensis and O.yadevi are categorised as pest species (Sundararaj and Shanbhag, 2013, Amina et al., in press). They are favoured by disturbance and are hence good colonizers. As per Sundararaj and Shanbhag (2013) and Varma and Swaran (2007), O. obesus was the dominant species in plantations. In the present study too, coffee and teak plantations were very rich in $O$. obesus.

According to Susilo and Aini (2005), the termite diversity and density decreased with increasing land use intensification, which destroyed the termite microhabitats and their nesting and feeding sites. The lower level of species diversity and richness of termites observed in plantations than those in the natural semi evergreen forest in this study truly authenticates the findings of Susilo and Aini (2005).

As of Attingnon et al., 2005, plantations were dominated with fungal feeders, while the organic/humus feeders frequented most, in the forest area. As the termites are indicators of soil fertility, the presence of organic rich feeders/ humus feeders like D. incola, $S$. chadaensis and $P$. near fletcheri reflected upon the higher soil fertility in the forest region than that of the plantations. The studies conducted by Eggleton et al. (1997), Eggleton et al. (2002), and DeSouza and Brown (1994) proved that the soil feeders were more vulnerable to human interference than wood feeders and this justifies the absence of soil feeders, the Apicotermitinae in plantations in the present study.

\section{CONCLUSIONS}

Of the three sites compared for termite assemblages, the semi evergreen forest site topped in species diversity, richness, evenness and in the occurrence of maximum number of functional groups. For the same reason, this forest area can be interpreted to be ecologically healthier and more stable than plantations. On the other hand, the presence of pest species in semi evergreen forests, though in lesser numbers, may be an early indication of the increasing disturbances on the habitat. Habitat homogeneity of plantations was reflected in their species similarity.

The vivid agreement between the sampled termite assemblages and structural attributes of different habitats advocates termites as good biological indicators of habitat quality. 


\section{ACKNOWLEDGEMENTS}

The authors are grateful to the Director, Zoological Survey of India (ZSI), Kolkata and the Officer-in-Charge, ZSI, Western Ghats Regional Centre, Calicut, Kerala, for support and encouragement. The second author is also thankful to MANF, awarded by the UGC for supporting this study.

\section{REFERENCES}

Amina, P., Rajmohana. K., Bhavana K.V. and Rabeeha. (2014). A few new records of Termite species to the state (Isoptera-Termitidae) Kerala, Journal of Threatened Taxa (in press).

Attignon, S.E., Lachat, T., Sinsin, B., Nagel, P. and Ralf, P. (2005). Termite assemblages in West - African Semi deciduous forest and teak. Agriculture, Ecosystems and Environment, $110,318-326$.

Bignell, D.E and Eggleton, P. (2000). Termites in ecosystems. In: Abe, T., Bignell, D.E. and Higashi, M. (Ed.) Termites: Evolution, Sociality, Symbioses, Ecology Kluwer Academic Publishers, Dordrecht, 363 - 87.

Bignell, D.E., Roisin, Y. and Lo, N. (2010). Biology of termites: A modern synthesis. Dordrecht: Springer, $x i v+576$ pp.

Chhotani, O.B (1997). The fauna of India and the adjacent countries. Isoptera (Termites): (Family Termitidae). Vol.2. Calcutta: Zoological Survey of India, $x x+800$ pp.

Collins, N.M. (1983). Termite populations and their role in litter removal in Malaysian rain forests. 311 - 325. In: Sutton, S. L., Whitmore, T. C. and Chadwick, A.C. (Eds) Tropical rain forest: Ecology and management. Blackwell Scientific Publications, Oxford.

Davies, R.G., Hernandez, L.M., Didham, R.K., Fagan, L.L. and Winchester, N.N. (2003). Environmental and spacial influences upon species composition of a Termite assemblage across Neotropical forest islands. Journal of Tropical Ecology, 19, 509 - 524.

DeBlauwe, I., Dibog, L., Missoup, A.D., Dupain, J., Van Elsacker, L., Dekoninck, W., Bonte, D. and Hendrickx, F. (2008). Spatial scales affecting termite diversity in tropical low land rainforest: a case study in southeast Cameroon. African Journal of Ecology, 46, 5 - 8.

DeSouza, O.F.F. and Brown, V.K. (1994). Effects of habitat fragmentation on Amazonian termite communities. Journal of Tropical Ecology, 10, 197 - 206.

Dibog, L., Eggleton, P., Norgrove, L., Bignell, D.E. and Hauser, H. (1999). Impacts of canopy cover on soil termite assemblages in an agrisilvi cultural system in Southern Cameroon. Bulletin of Entomological Research, 89, 125 - 132.

Donovan, S.E., Eggleton, P. and Bignell, D.E. (2001). Gut content analysis and a new feeding group classification of termites. Ecological Entomology, 26(4), 356 - 366. 
Donovan, S.E., Eggleton, P. and Martin, A (2002). Species composition of termites of the Nyika plateau forests, northern Malawi, over an altitudinal gradient. African Journal of Ecology, 40, 379 - 385.

Eggleton, P., Bignell, D.E., Hauser, S., Dibog, L., Norgrove, L., Madong, B. (2002). Termite diversity across an anthropogenic disturbance gradient in the humid forest zone of West Africa. Agriculture Ecosystems \& Environment, 90, 189 - 202.

Eggleton, P., Bignell, D.E., Sands, W.A., Mawdsley, N.A., Lawton, J.H., Wood T.G. and Bignell, N.C. (1996). The Diversity, abundance and biomass of termites under differing levels of disturbance in the Mbalmayo Forest Reserve, Southern Cameroon.Philosophical Transactions of the Royal Society of London. Ser. B. Biological Sciences, 351, 51 - 68.

Eggleton, P., Homathevi, R., Jeeva, D., Jones, D.T., Davies, R.G. and Maryati, M. (1997). The species richness and composition of termites (Isoptera) in primary and regenerating lowland dipterocarp forest in Sabah, East Malaysia. Ecotropica, 3, 119 - 128.

Gathorne-Hardy, Syaukani, F. and Eggleton, P. (2001). The effect of altitude and rainfall on the composition of termites (Isoptera) of the Leuser Ecosystem (Sumatra, Indonesia). Journal of Tropical Ecology, 17, 379 - 393.

Gowda, D.K.S., Venkatesha, M.G. and Bhat, P.K. (1995). Preliminary observations on the incidence of termites on coffee and its shade trees. Journal of coffee research, 25(1), 30 - 34.

Jaccard, P. (1912). The distribution of the flora in the alpine zone. New Phytologist, 11(2), $37-50$.

Jones, D.T. (2000). Termite assemblages in two distinct montane forest types at $1000 \mathrm{~m}$ elevation in the Maliau Basin, Sabah. Journal of Tropical Ecology, 16, 271 -286.

Jones, D.T. and Brendell, M.J.D. (1994). The termite (Insecta: Isoptera) fauna of Pasoh Forest Reserve, Malaysia. Raffles Bulletin of Zoology, 46(1), 79 - 91.

Jones, D.T and Eggleton, P. (2000). Sampling termite assemblages in tropical forests: testing a rapid biodiversity assessment protocol. Journal of Applied Ecology, 37, 191 - 203.

Jones, D.T., Susilo, F.X., Bignell, D.E., Hardiwinoto, S., Gillison, A.N. and Eggleton, P. (2003).Termite assemblage collapse along a Land-use intensification gradient in lowland central Sumatra, Indonesia.Journal of Applied Ecology, 40, 380 - 391.

Magurran, E.A. (1988). Ecological Diversity and its Measurement. Croom Helm, Australia, $179 \mathrm{pp}$.

Margalef, R. (1958). Temporal succession and spatial heterogeneity in phytoplankton. In: Perspectives in Marine biology, University of California Press, Berkeley, 323-347 pp.

Matsumoto, T and Abe, T. (1979). The role of termites in an equatorial rain forest ecosystem of west Malaysia. 2. Leaf litter consumption on the forest floor. Oecologia, 38, 261 - 274.

Meyr, J.R. (2009). General Entomology, Isoptera-

http://www.cals.ncsu.edu/course/ent425/library/compendium/isoptera.html 
Pielou, E.C. (1966). The measurement of diversity in different types of biological collections. Journal of Theoretical Biology, 13, 131 - 144.

Shannon C.E and Wiener, W. (1949). The mathematical theory of communication. Urbana, University of Illinois Press, $177 \mathrm{pp}$.

Simpson, E.H. (1949). Measurement of species diversity. Nature, 163, 688.

Sundararaj, R and Shanbhag, R.R. (2013). Assemblage and species diversity of wood destroying termites in different land use systems in Western Ghat, India. Journal of forestry Research, 24(2), 361 - 365.

Susilo, F.X. and Aini, F.K. (2005). Diversity and density of termites in arrange of land use types in the rigis hill area, sumberjaya - Lampung. J. Sains Tec., 11(3), 129 - 133.

Varma, R.V. and Swaran, P.R. (2007). Diversity of termites in a young eucalypt plantation in the tropical forests of Kerala, India. International Journal of Tropical Insect Science, 27(2), $95-101$.

Wood, T.G. (1996).The agricultural importance of termites in the tropics. Agricultural Zoology Reviews, 7, 117 - 155.

Wood, T.G. and Sands, W.A. (1978).The role of termites in Ecosystems. In: Brian, M.V. (Ed.) Production ecology of ants and termites. Cambridge University Press, Cambridge, $245-292$. 